\title{
Hot or not? Discovery and characterization of a thermostable alditol oxidase from Acidothermus cellulolyticus 11B
}

\author{
Remko T. Winter • Dominic P. H. M. Heuts • \\ Egon M. A. Rijpkema • Edwin van Bloois • \\ Hein J. Wijma • Marco W. Fraaije
}

Received: 26 August 2011 /Revised: 1 November 2011 / Accepted: 17 November 2011 /Published online: 11 January 2012

(C) The Author(s) 2012. This article is published with open access at Springerlink.com

\begin{abstract}
We describe the discovery, isolation and characterization of a highly thermostable alditol oxidase from Acidothermus cellulolyticus 11B. This protein was identified by searching the genomes of known thermophiles for enzymes homologous to Streptomyces coelicolor A3(2) alditol oxidase (AldO). A gene (sharing $48 \%$ protein sequence identity to AldO) was identified, cloned and expressed in Escherichia coli. Following 6xHis tag purification, characterization revealed the protein to be a covalent flavoprotein of $47 \mathrm{kDa}$ with a remarkably similar reactivity and substrate specificity to that of AldO. A steady-state kinetic analysis with a number of different polyol substrates revealed lower catalytic rates but slightly altered substrate specificity when compared to AldO. Thermostability measurements revealed that the novel AldO is a highly thermostable enzyme with an unfolding temperature of $84{ }^{\circ} \mathrm{C}$ and an activity half-life at $75^{\circ} \mathrm{C}$ of $112 \mathrm{~min}$, prompting the name HotAldO. Inspired by earlier studies, we attempted a
\end{abstract}

Electronic supplementary material The online version of this article (doi:10.1007/s00253-011-3750-0) contains supplementary material, which is available to authorized users.

R. T. Winter · E. M. A. Rijpkema • E. van Bloois $\cdot$ H. J. Wijma $\cdot$ M. W. Fraaije $(\square)$

Laboratory of Biochemistry,

Groningen Biomolecular Sciences and Biotechnology Institute,

University of Groningen,

Nijenborgh 4,

9747 AG, Groningen, The Netherlands

e-mail: m.w.fraaije@rug.nl

URL: http://www.rug.nl/staff/m.w.fraaije/index

D. P. H. M. Heuts

Manchester Interdisciplinary Biocentre

and Faculty of Life Sciences,

University of Manchester,

131 Princess Street,

Manchester M1 7DN, UK straightforward, exploratory approach to improve the thermostability of AldO by replacing residues with high Bfactors with corresponding residues from HotAldO. None of these mutations resulted in a more thermostable oxidase; a fact that was corroborated by in silico analysis.

Keywords Carbohydrate oxidase · Flavoenzyme . Thermostable $\cdot$ ThermoFAD $\cdot$ Alditols

\section{Introduction}

The importance of enzymes as industrial biocatalysts has been steadily increasing over the past decades (Pollard and Woodley 2007; Sheldon 2008; Wohlgemuth 2009). Their exquisite chemo-, regio- and enantioselectivity make them extremely powerful, and recent trends forcing the chemical industry to become more sustainable are making the development of enzymatic processes more attractive as replacements for conventional, less sustainable procedures. A major drawback of enzymatic processes is that optimal physiological conditions often do not translate well into industrial processes, with the thermostability of the protein proving to be a major challenge for enzyme engineers.

One of the most important reactions in synthetic organic chemistry is the oxidation of primary and secondary alcohols; both the alcohol and its oxidation product are being used as building blocks in numerous synthetic routes. Chemical alcohol oxidation on an industrial scale often proceeds via methods involving stoichiometric amounts of heavy metals like chromium and manganese. While the recent advances in transition metal-catalyzed (Punniyamurthy et al. 2005) and organocatalytic (Wong and Shi 2008) oxidations using $\mathrm{O}_{2}$ and $\mathrm{H}_{2} \mathrm{O}_{2}$ as oxidants are impressive, biocatalytic alternatives - which are both environmentally benign and more selective-are 
obviously highly desirable. Several oxidizing enzymes can be utilized in processes requiring the selective oxidation of alcohols, with alcohol dehydrogenases which catalyze the oxidation of an alcohol into a ketone with the concomitant reduction of the electron acceptor $\mathrm{NAD}(\mathrm{P})^{+}$being used most extensively (Liese and Seelbach 2006). The obvious drawback of these enzymes is the fact that they require stoichiometric amounts of an expensive cofactor, and for this reason, the alcohol/carbohydrate oxidases have been attracting recent interest (van Hellemond et al. 2006). These enzymes utilize molecular oxygen as a cheap and clean electron acceptor, which is reduced to hydrogen peroxide yielding the only byproduct of the reaction. Positive aspects notwithstanding, there are at present relatively few of these enzymes available. Most, like the well-studied glucose oxidase (Bankar et al. 2009), are eukaryotic in origin, and consequently, issues like expression and post-translational modifications are problematic. In this regard, the flavoprotein alditol oxidase (AldO), recently identified from the proteome of S. coelicolor A3(2) (Heuts et al. 2007), is unique insofar that it is bacterial in origin and heterologous expression is not an issue. AldO has been studied for its biocatalytic potential (van Hellemond et al. 2009), and recent studies on the display of AldO on the cell surface and in the periplasm of E. coli heighten its possible application as a (whole-cell) biocatalyst (van Bloois et al. 2009; 2011). Since its discovery, two patents have been issued involving the biocatalytic application of AldO (WO 2008/ 051491 A2, Danisco US; WO 2007/054203 A2, Henkel AG), highlighting its industrial potential. AldO is a $45 \mathrm{kDa}$ monomeric flavoprotein, expressed at high yields in E. coli (up to $350 \mathrm{mg} \mathrm{L}^{-1}$ ) and capable of selectively oxidizing the primary hydroxyl group of alditols, with xylitol being the best substrate. Its substrate specificity is relatively relaxed, with a broad range of aliphatic alcohols being converted. Notably, AldO is highly regio- and enantioselective for the oxidation of 1,2-diols, forming enantiopure alpha-hydroxy carboxylic acids (van Hellemond et al. 2009). Despite these attractive characteristics, the utilization of AldO in biocatalytic processes is limited by the fact that it is only moderately thermophilic with an activity half-life at $30{ }^{\circ} \mathrm{C}$ of only $30 \mathrm{~h}$ (van Hellemond et al. 2009) and an unfolding temperature $\left(T_{\mathrm{m}}\right)$ of $61{ }^{\circ} \mathrm{C}$. Hence, the aim of this study was to identify a thermostable oxidase with the desirable biocatalytic properties of AldO, by searching bacterial genome databases. The secondary aim was then to reverse engineer this thermostability into AldO, thus gaining valuable insight into the mechanisms responsible for the thermal stability of these redox enzymes.

By genome mining, a homologue of alditol oxidase (AldO) was discovered in the genome of the thermophilic bacterium A. cellulolyticus 11B, an organism isolated from the acidic hot springs of northern Yellowstone National
Park, WY, USA (Barabote et al. 2009; Mohagheghi et al. 1986). Heterologous expression in E. coli, purification and characterization revealed a thermostable flavoprotein with highly similar substrate specificity to AldO. The unfolding temperature $\left(T_{\mathrm{m}}\right)$ was determined to be more than $20{ }^{\circ} \mathrm{C}$ higher than AldO, inspiring the name HotAldO for this protein. Inspired by earlier studies (Reetz et al. 2006), we attempted to improve the thermostability of AldO by replacing residues with high B-factors with corresponding residues from HotAldO. None of these mutations resulted in a more thermostable oxidase; a fact that was corroborated by in silico analysis.

With an increasing need for robust biocatalysts and the emerging importance of green, enzymatic oxidations (Hollmann et al. 2011), we believe that the discovered thermostable HotAldO described here is a valuable addition to the industrial enzyme toolbox.

\section{Materials and methods}

\section{Reagents and enzymes}

Restriction enzymes were obtained from New England Biolabs. The polymerase chain reaction (PCR) was carried out with the Expand Long Range PCR kit from Roche. QuikChange mutants were constructed using PfuTurbo DNA polymerase from Stratagene. Vanillyl alcohol oxidase (VAO; EC 1.1.3.38) was a kind gift from Prof. Dr. W. J. H. van Berkel (Wageningen University, The Netherlands). Horseradish peroxidase (EC 1.11.1.7) was from Fluka. $\mathrm{Ni}^{2+}$ NTA agarose was obtained from Qiagen. All other chemicals used were from Sigma-Aldrich and of analytical grade.

Cloning and expressing the hotaldo gene and generation of thermostability mutants

A. cellulolyticus 11B (ATCC ${ }^{\circledR}$ no: 43068) genomic DNA was obtained from LGC Standards (Teddington, UK). The gene encoding HotAldO (KEGG entry: Acel_0723) was amplified from $A$. cellulolyticus $11 \mathrm{~B}$ genomic DNA by PCR (primers available upon request). A synthetic gene encoding the HotAldO protein (RefSeq code: YP_872482) and optimized for expression in E. coli was obtained from GENEART (Regensburg, Germany). The gene (KEGG entry: Tfu_1946) encoding the putative thermostable alditol oxidase from Thermobifida fusca YX (TfuAldO; RefSeq code: YP 290002) was amplified from genomic DNA by PCR (primers available upon request). All three genes were cloned into the pBADNdeIHis and pBAD-MBP expression vectors between the restriction sites NdeI/Pst $\mathrm{I}$ and EcoRI/ Pst $\mathrm{I}$, respectively. pBADNdeIHis is a pBAD/myc-HisA-derived expression vector (Invitrogen) in which the NdeI site is 
removed and the $N c o$ I site is replaced by $N d e I$ (Jin et al. 2007). In this vector, the myc-HisA epitope has also been removed and replaced by a $6 x$ His tag immediately downstream of the C-terminal PstI site. pBAD-MBP is identical to $\mathrm{pBADNdeIHis}$ save for the $N d e \mathrm{I} / E c o R \mathrm{I}$ insertion of the malE gene and a factor Xa protease cleavage site from pMALc2x (New England Biolabs). The resulting expression plasmids, pBAD $(\mathrm{m}) \mathrm{HAG}$ (HotAldO cloned from genomic DNA; m, MBP fusion), pBAD(m)HAS (HotAldO cloned from synthetic DNA; m, MBP fusion) or $\mathrm{pBAD}(\mathrm{m}) T f u \mathrm{Ox}$ ( $T f u \mathrm{Ox}$, putative thermostable oxidase cloned from Thermobifida fusca; m, MBP fusion) were used to transform E. coli TOP10 (Invitrogen), MC1061 (Casadaban and Cohen 1980) and BL21(DE3) (Studier and Moffatt 1986) cells. Transformed strains were cultured to saturation at $37{ }^{\circ} \mathrm{C}$ in Luria Bertani medium (LB; $10 \mathrm{~g}$ tryptone, $5 \mathrm{~g}$ yeast extract and $10 \mathrm{~g}$ $\mathrm{NaCl}$ per liter). In all cases, medium was supplemented with $50 \mu \mathrm{g} \mathrm{mL}^{-1}$ ampicillin. Saturated cultures were back diluted 1:100 into fresh LB medium containing $0.02 \%(w / v)$ Larabinose and cultured at $17{ }^{\circ} \mathrm{C}, 25^{\circ} \mathrm{C}, 30^{\circ} \mathrm{C}$ and $37{ }^{\circ} \mathrm{C}$ for $72,18,16$ and $12 \mathrm{~h}$, respectively, to determine the optimal expression conditions for HotAldO. Expression levels were analyzed with sodium dodecyl sulfate-poly acrylamide gel electrophoresis (SDS-PAGE) by comparing to uninduced controls.

S. coelicolor A3(2) alditol oxidase (AldO) thermostability QuikChange mutants (Table 2) were generated by sitedirected mutagenesis using PfuTurbo polymerase (primer sequences available on request) and $\mathrm{pBAD}$-aldo (Heuts et al. 2007) as template. Due to the high GC content (73.4\%) of the AldO gene, the QuikChange mutagenesis protocol (Stratagene) was slightly modified. Briefly, QuikChange mixes contained $0.4 \mu \mathrm{M}$ forward and reverse primers, 0.2 $\mathrm{mM}$ dNTPs, $50 \mathrm{ng}$ template, polymerase buffer, $2.5 \mathrm{U}$ polymerase, $4 \%(\mathrm{v} / \mathrm{v})$ DMSO and sterile double distilled $\mathrm{H}_{2} \mathrm{O}$ to a final volume of $50 \mu \mathrm{l}$. The following PCR program was run on a TECHNE thermocycler: $5 \mathrm{~min}$ initial denaturation at $94{ }^{\circ} \mathrm{C}$ followed by 18 identical cycles consisting of a $1 \mathrm{~min}$ denaturation step at $94^{\circ} \mathrm{C}$, a 0.5 min annealing step at $55^{\circ} \mathrm{C}$ and a $13 \mathrm{~min}$ extension step at $68^{\circ} \mathrm{C}$. The program was ended with a final extension step of $5 \mathrm{~min}$ at $68{ }^{\circ} \mathrm{C}$. Nucleotide sequences were verified by DNA sequencing (GATC Biotech Ag, Konstanz, Germany). E. coli MC1061 cells were transformed with AldO mutants and expressed in $50 \mathrm{~mL}$ Terrific Broth medium (TB; $12 \mathrm{~g}$ bacto tryptone, $24 \mathrm{~g}$ yeast extract, $4 \mathrm{~mL}$ glycerol, $16.4 \mathrm{~g} \mathrm{~K}_{2} \mathrm{HPO}_{4} \cdot 3 \mathrm{H}_{2} \mathrm{O}$ and $2.3 \mathrm{~g} \mathrm{KH}_{2} \mathrm{PO}_{4}$ per liter) supplemented with $50 \mu \mathrm{g} \mathrm{mL}^{-1}$ ampicillin and $0.02 \%$ (w/v) L-arabinose for $72 \mathrm{~h}$ at $17{ }^{\circ} \mathrm{C}$.

Purification of recombinant HotAldO

Optimal protein expression was obtained by culturing $E$. coli TOP10 cells harboring pBADHAS in TB supplemented with $50 \mu \mathrm{g} \mathrm{mL} \mathrm{m}^{-1}$ ampicillin and $0.02 \%(\mathrm{w} / \mathrm{v})$ L-arabinose at $37^{\circ} \mathrm{C}$ for $12 \mathrm{~h}$. Cells from $1 \mathrm{~L}$ of culture were harvested by centrifugation $\left(6,000 \times \mathrm{g}\right.$ for $15 \mathrm{~min}$ at $\left.4{ }^{\circ} \mathrm{C}\right)$, resuspended in $30 \mathrm{~mL}$ potassium phosphate buffer $(50 \mathrm{mM}, \mathrm{pH} 7.5)$ and disrupted by sonication $\left(20 \mathrm{kHz}\right.$ for $15 \min$ at $\left.4{ }^{\circ} \mathrm{C}\right)$. Following a clarifying centrifugation step $\left(23,000 \times g\right.$ for $30 \mathrm{~min}$ at $\left.4{ }^{\circ} \mathrm{C}\right)$ to remove cell debris, $6 \mathrm{xHis}$ labeled HotAldO was purified from the supernatant using $\mathrm{Ni}^{2+}$-NTA agarose as described earlier (van Bloois et al. 2010). Briefly, $\mathrm{NaCl}$ and imidazole were added to a concentration of $500 \mathrm{mM}$ and $15 \mathrm{mM}$, respectively, and incubated with $\mathrm{Ni}^{2+}$-NTA agarose $\left(1.5 \mathrm{~mL}\right.$, Qiagen) for $120 \mathrm{~min}$ at $4{ }^{\circ} \mathrm{C}$. The slurry was loaded into a chromatography column (BioRad, PolyPrep) and washed with potassium phosphate buffer $(50 \mathrm{mM}, \mathrm{pH}$ 7.5) containing $500 \mathrm{mM} \mathrm{NaCl}$ and, successively, 15 and $30 \mathrm{mM}$ imidazole. HotAldO was eluted with $60 \mathrm{mM}$ imidazole. Imidazole and $\mathrm{NaCl}$ were removed by applying the enzyme to an Econo-Pac ${ }^{\circledR}$ 10DG desalting column (BioRad). Desalted HotAldO was concentrated using an Ami$\operatorname{con}^{\circledR}$ Ultra $0.5 \mathrm{~mL}$ centrifugal filter (Millipore, 12000 MWCO). The purification procedure was monitored by analyzing samples for xylitol oxidase activity and by SDS-PAGE.

S. coelicolor A3(2) alditol oxidase (AldO) was heterologously expressed in E. coli MC1061 cells with the pBAD-aldo (Heuts et al. 2007) expression vector. Cells were cultured in TB supplemented with $50 \mu \mathrm{g} \mathrm{mL}^{-1}$ ampicillin and $0.02 \%(\mathrm{w} / \mathrm{v})$ L-arabinose for $72 \mathrm{~h}$ at $17{ }^{\circ} \mathrm{C}$. Purification of AldO was carried out on an Äkta purifier (GE Healthcare) with a Q-Sepharose column, as described previously (Heuts et al. 2007).

\section{Analytical methods}

Unless stated otherwise, all experiments were performed at $25^{\circ} \mathrm{C}$ and in potassium phosphate buffer (50 mM, pH 7.5). All measurements were carried out in triplicate, and the standard deviation value in the experiments is $<5 \%$, unless stated otherwise. Absorption spectra of HotAldO were recorded on a Perkin-Elmer LambdaBio40 spectrophotometer. The extinction coefficient was calculated by comparing the absorption spectra before and after denaturing with $0.1 \%$ SDS. The oligomeric form of HotAldO was determined as described previously (van Bloois et al. 2010), using a WorkBeads SEC40 prepacked column (15 mL; Bio-Works, Hong Kong) and potassium phosphate buffer $(50 \mathrm{mM}, \mathrm{pH} 7.5)$ containing $150 \mathrm{mM} \mathrm{KCl}$.

\section{Steady-state kinetic parameters}

An indirect assay coupling the production of hydrogen peroxide by HotAldO or AldO to the horseradish peroxidase (HRP) mediated oxidation of 4-aminoantipyrine 
(AAP) and 3,5-dichloro-2-hydroxybenzenesulfonic acid (DCHBS) was used to measure oxidase activity and determine the kinetic parameters of HotAldO and AldO. In this assay, the formation of a pink/purple colored product can be measured spectrophotometrically at $515 \mathrm{~nm}\left(\varepsilon_{515 \mathrm{~nm}}=\right.$ $26 \mathrm{mM}^{-1} \mathrm{~cm}^{-1}$ ) (Federico et al. 1997). A typical reaction mixture contained $0.1 \mathrm{mM}$ AAP, $1 \mathrm{mM}$ DCHBS, 3 units HRP and 20-nM enzyme, as described earlier (Heuts et al. 2007). To determine the $\mathrm{pH}$ optimum of HotAldO and AldO, the aforementioned assay was performed in three different buffer systems: $50 \mathrm{mM}$ citrate (pH 4.6-6.0), 50 $\mathrm{mM}$ phosphate $(\mathrm{pH} 6.0-8.3)$ and $50 \mathrm{mM}$ glycine $(\mathrm{pH} 8.6-$ 10.2).

\section{Pre-steady-state kinetic studies}

An Applied Photophysics stopped-flow apparatus, model SX17MV, was used. Absorption spectra were collected at $2.5 \mathrm{~ms}$ intervals using a diode array detector, while absorption at single wavelengths was followed in time with a photomultiplier detector. Spectral data obtained by diode array measurements were deconvoluted using Pro-K software (Applied Photophysics). The reductive half-reaction was monitored by collecting spectra with the diode array detector and by measuring the absorbance over time at $452 \mathrm{~nm}$ with the photomultiplier detector after anaerobically mixing $12 \mu \mathrm{M}$ enzyme with varying concentrations of xylitol. The oxidative halfreaction was followed at $452 \mathrm{~nm}$ with the photomultiplier detector after mixing a solution containing reduced enzyme $(12 \mu \mathrm{M})$ with a buffer solution containing $31.25,62.5$ or $125.0 \mu \mathrm{M}$ dioxygen. Anaerobic conditions were created by the addition of $1 \mathrm{mM} 4-$ ethylphenol to all solutions and flushing with nitrogen. Subsequently, VAO was added to a final concentration of $100 \mathrm{nM}$ to remove all traces of residual oxygen. Traces obtained with the photomultiplier tube were fitted to an exponential function (Eq. 1),

$A(t)=A+C \times e^{(-k t)}$,

where $A$ is the absorption, $C$ is a constant and $k$ is an observed rate constant. The observed rates for substrateconcentration-dependent reduction of HotAldO were fitted using the following equation (Eq. 2),

$k_{\mathrm{obs}}=\frac{k_{\mathrm{red}} \times S}{K_{\mathrm{d}}+S}$,

where $k_{\text {obs }}$ is an observed rate constant, $k_{\text {red }}$ is the reduction rate constant, $S$ is the substrate concentration and $K_{\mathrm{d}}$ is the dissociation constant.

\section{Assessing thermostability}

Thermostability was assessed by determining residual activity after incubation of the enzyme at high temperatures. Freshly purified $2 \mu \mathrm{M}$ aliquots of HotAldO or AldO were incubated in a water bath at the appropriate temperature. At set intervals, samples were removed and assayed for xylitol oxidase activity, as described previously. A constant xylitol concentration of $10 \mathrm{mM}$ was used. The percentage of residual activity was plotted against time, and from this plot, the half-life of the enzyme $\left(t_{1 / 2}{ }^{x^{\circ} \mathrm{C}}\right)$ was determined: the time at which the initial activity has dropped to $50 \%$ of the original activity after incubation at a certain temperature. The residual activity after incubation for $1 \mathrm{~h}$ at various temperatures was also plotted.

The temperature optimum of HotAldO and AldO was determined by measuring the initial xylitol oxidase activity at increasing temperatures. Reaction mixtures were prepared as described previously (10 $\mathrm{mM}$ xylitol, without enzyme) and equilibrated to a defined temperature using the spectrophotometer's Peltier. Enzyme was added, and the initial rate was measured. Temperature optimum was determined by plotting the observed activity as percentage of the maximum observed activity versus the temperature. Controls were carried out to ensure that there was sufficient HRP activity at elevated temperatures.

\section{Determining the unfolding temperature, $T_{m}$, using ThermoFAD}

The unfolding temperature, $T_{\mathrm{m}}$, of HotAldO was determined using the ThermoFAD method, a Thermofluor ${ }^{\circledR}$-derived approach for measuring the stability of flavoproteins based on the intrinsic fluorescence of their flavin cofactor and first described by Forneris et al. (2009). While this method does not assess the unfolding equilibrium, it is valuable for establishing the thermostability of a protein. In a real-time PCR (RT-PCR) machine (Eppendorf) fitted with a 470 $543 \mathrm{~nm}$ excitation filter and a SYBR Green emission filter $(523-543 \mathrm{~nm}), 20 \mu \mathrm{l}$ of $1 \mathrm{mg} \mathrm{mL}^{-1}$ protein were loaded. A temperature gradient from $20{ }^{\circ} \mathrm{C}$ to $90{ }^{\circ} \mathrm{C}$ was applied $\left(1^{\circ} \mathrm{C} \mathrm{min}^{-1}\right)$, and fluorescence data were recorded every $0.5{ }^{\circ} \mathrm{C}$ after a $10 \mathrm{~s}$ stabilization delay. A sigmoidal curve was obtained after plotting the fluorescence against the temperature. The unfolding temperature, $T_{\mathrm{m}}$, is then determined as the maximum of the derivative of this sigmoidal curve (Pantoliano et al. 2001).

Due to the high soluble overexpression levels of AldO in E. coli $\mathrm{MC1061}$, we modified this protocol to obtain accurate unfolding temperatures of AldO Quikchange thermostability mutants using cleared cell extracts instead of purified protein. Cells were harvested from $50 \mathrm{~mL}$ cultures 
by centrifugation $\left(6,000 \times g\right.$ for $15 \mathrm{~min}$ at $\left.4{ }^{\circ} \mathrm{C}\right)$, washed twice with potassium phosphate buffer $(50 \mathrm{mM}, \mathrm{pH} 7.5)$ and disrupted by sonication $\left(20 \mathrm{kHz}\right.$ for $15 \mathrm{~min}$ at $\left.4{ }^{\circ} \mathrm{C}\right)$. Following a clarifying centrifugation step $(23,000 \times g$ for $30 \mathrm{~min}$ at $4{ }^{\circ} \mathrm{C}$ ) to remove cell debris, the supernatant was desalted to remove free FAD by applying the enzyme to an Econo-Pac ${ }^{\circledR}$ 10DG desalting column (BioRad). Desalted cell extracts were concentrated using an Amicon ${ }^{\circledR}$ Ultra $0.5 \mathrm{~mL}$ centrifugal filter (Millipore, $12000 \mathrm{MWCO}$ ). In a RT-PCR machine, $20 \mu \mathrm{L}$ of concentrated, desalted cell extracts were loaded, and the $T_{\mathrm{m}}$ was determined as described previously.

\section{Computational analysis}

FoldX and Rosetta were used to predict the change in folding energy of the protein due to the mutation $\left(\Delta \Delta \mathrm{G}^{\mathrm{FOLD}}\right.$ ). FoldX was originally designed (Guerois et al. 2002) to predict the $\Delta \Delta \mathrm{G}^{\mathrm{FOLD}}$ and was calibrated on a set of 1,088 single mutants with an average error of $3.4 \mathrm{~kJ} \mathrm{~mol}^{-1}$ (this error did not include $5 \%$ outliers). Rosetta is a more general molecular modeling software package which was recently adopted for the prediction of $\Delta \Delta \mathrm{G}^{\mathrm{FOLD}}$ (Kellogg et al. 2011). While Rosetta was shown to exhibit better prediction trends ( $r=0.67$, versus 0.5 for FoldX), no error expressed in kilojoule per mole was reported for Rosetta, and therefore, an error of $5 \mathrm{~kJ} \mathrm{~mol}^{-1}$ was assumed. For Rosetta, the protocol described earlier was used, which includes repacking of all residues in the protein with a softrep function (Kellogg et al. 2011). With the soft-rep ('soft repulsion') function, the repulsive energy does not increase as dramatically when two atoms are brought together. As a result, clashes are penalized less throughout the initial stages of a discrete optimization. A model of the Asp deletion mutant was made with Yasara (Krieger et al. 2009).

MD simulations were used to predict the root mean square fluctuations (RMSF), which is a measure of protein flexibility. MD simulation with the Yamber3 force field (Krieger et al. 2004) was carried out under Yasara (Krieger et al. 2002). The 1.1- $\AA$ resolution X-ray structure of ligand free AldO (Forneris et al. 2008) was used (2VFR) for the MD simulation. The rectangular simulation box extended at least $7.5 \AA$ from each side of the protein and contained 23 sodium and 12 chloride atoms to neutralize the net negative charge of AldO. The MD simulation was run with LINCS (Hess et al. 1997) and SETTLE (Miyamoto and Kollman 1992), with a timestep of $2 \mathrm{fs}$, and with periodic boundary conditions. Snapshots were taken every 10 ps between 2 and $7 \mathrm{~ns}$ (the first $2 \mathrm{~ns}$ was used for equilibration) and were used to calculate the RMSF. For all other details regarding the MD simulation, see Westerbeek et al. (2011). For comparison to the thus predicted RMSF free in solution, the RMSF of the crystal structure was calculated from its B-factors via $\mathrm{RMSF}=\sqrt{ }\left(3 / 8 \mathrm{~B}-\right.$ factor $\left./ \pi^{2}\right)$.

\section{Sequence analysis}

HotAldO was identified by PSI-BLAST searches of the NCBI bacterial genome sequence database. Sequence alignment was performed with ClustalW version 2.0 (Larkin et al. 2007) with subsequent manual refinements. The structural model of HotAldO was constructed using the CPHmodels 3.0 server (Nielsen et al. 2010) (http://www.cbs.dtu.dk/ services/CPHmodels/) and the crystal structure of AldO complexed with xylitol (Protein Data Bank, PDB id: 2VFS). Pictures were generated using PyMOL software (http://www.pymol.org/).

\section{Results}

Identification, expression, purification and spectral characterization of HotAldO

The protein sequence of $S$. coelicolor A3(2) alditol oxidase (UniProt: Q9ZBU1), a prototype flavoprotein oxidase belonging to the VAO family, was used to perform PSIBLAST searches to identify putative oxidases. Several sequences were identified, which originated from thermophilic organisms (Fig. 1), including two from the actinomycetes Thermobifida fusca YX and A. cellulolyticus 11B. Both were attractive sources for putative thermostable oxidases; we have shown before that Thermobifida fusca is a good source of robust biocatalysts (van Bloois et al. 2010; Fraaije et al. 2005) and A. cellulolyticus is known to produce many thermostable cellulose degrading enzymes, including an endoglucanase, E1, which is thermostable to $81{ }^{\circ} \mathrm{C}$ (Sakon et al. 1996). The fact that both organisms are obligate thermophiles with an optimal growth temperature (OGT) of $55^{\circ} \mathrm{C}$ and no growth below $37^{\circ} \mathrm{C}$ (Barabote et al. 2009; Lykidis et al. 2007) improved the chances of finding a thermostable oxidase within their genomes. The putative thermostable oxidase from Thermobifida fusca (KEGG entry: Tfu_1946; RefSeq code: YP_290002) consists of 433 amino acids and has a theoretical mass of $48.0 \mathrm{kDa}$ (minus FAD); a homologous protein from $A$. cellulolyticus (KEGG entry: Acel_0723; RefSeq code: YP_872482) is only 417 amino acids in length and has a theoretical mass of $46.0 \mathrm{kDa}$ (minus FAD). Both proteins share high homology to the previously studied flavoprotein oxidases AldO (Heuts et al. 2007) (31\% and $48 \%$ sequence identity, respectively) and Streptomyces sp. IKD472 xylitol oxidase (Yamashita et al. 2000) (XylOx, 27\% and 48\% sequence identity, respectively) and contain the conserved FAD-linking histidine (Fig. 1). High levels of soluble and 
HotAldO

Aldo

TfuOx

HotAldO

Aldo

Tfuox

HotAldO

Aldo

TfuOx

HotAldO

Aldo

TfuOx

HotAldo

TfuOx

HotAldO

HotAldO

Aldo

TfuOx

HotAldO

Aldo

TfuOx
Aldo

Aldo

TfuOx
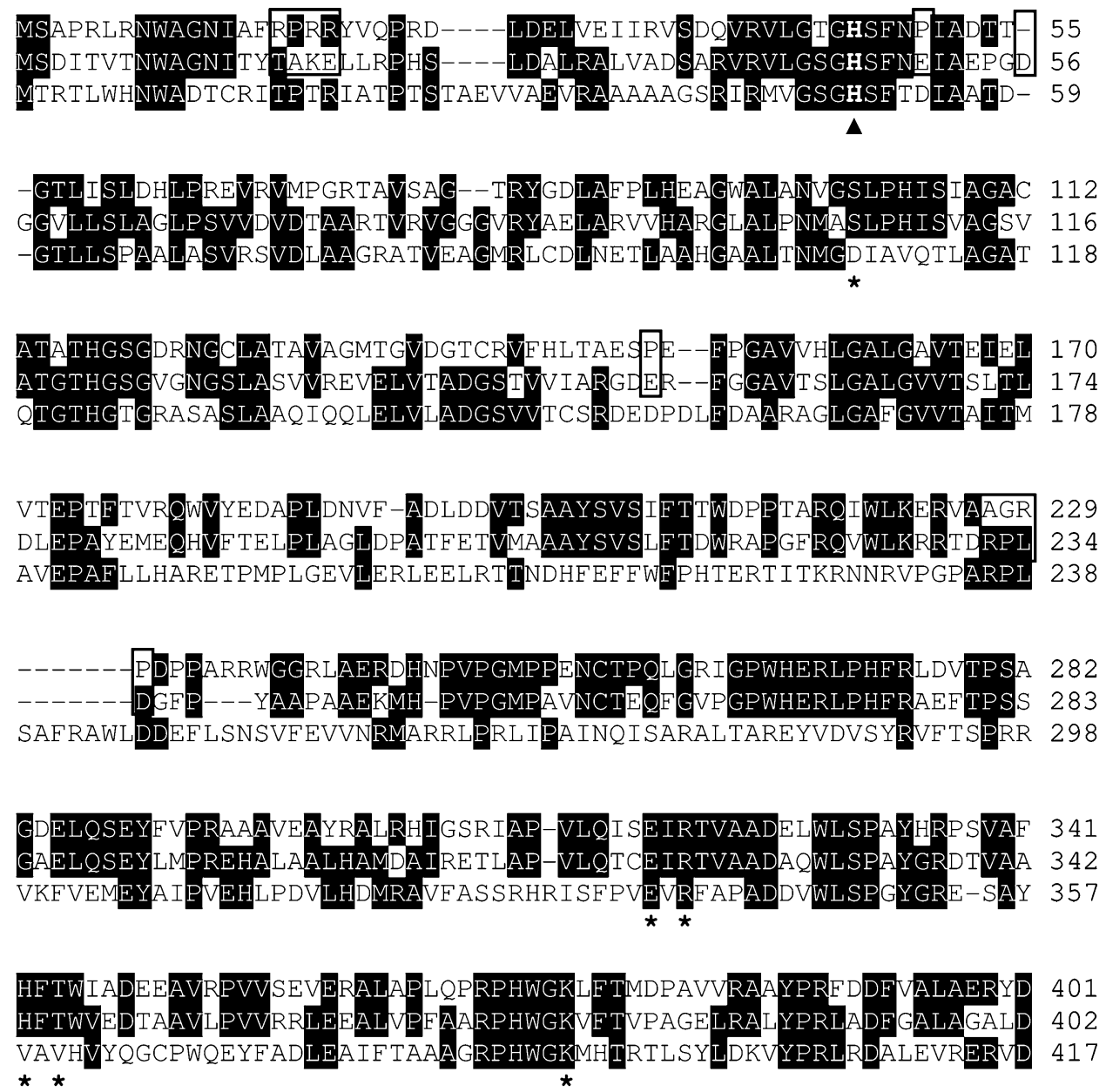

MDPAVVRAAYPRE
PPAGELRALYPRL

* *

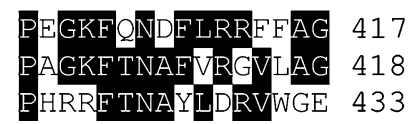

Fig. 1 Multiple sequence alignment of AldO-type oxidases generated with ClustalW. Conserved residues are shaded, numbers refer to amino acid numbers, and dashes correspond to gaps in the sequence alignment. The conserved FAD-binding histidine is in bold and marked with an arrowhead. Residues involved in substrate binding and catalysis are marked with an asterisk. HotAldO, thermostable alditol oxidase from

covalently flavinylated expression of the putative thermostable oxidase from Thermobifida fusca were achieved in $E$. coli TOP 10 cells cultured at $17^{\circ} \mathrm{C}$, but a substrate screen of 86 potential oxidase substrates (Heuts et al. 2007; van Hellemond et al. 2009), which included a wide variety of aliphatic and aromatic amines and alcohols, did not yield a positive result. As a result, we decided to focus on the expression and characterization of the putative thermostable oxidase from A. cellulolyticus, HotAldO.

To enable heterologous expression, the gene encoding HotAldO was PCR amplified from A. cellulolyticus genomic DNA and cloned into the arabinose inducible pBAD expression vector. With the resulting pBADHAG expression vector, recombinant expression in E. coli BL21(DE3),
A. cellulolyticus 11B (RefSeq code: YP_872482); AldO, alditol oxidase from S. coelicolor A3(2) (UniProt: Q9ZBU1); TfuOx, putative thermostable oxidase from Thermobifida fusca YX (RefSeq code: YP 290002). Boxed are the AldO residues that have the highest Bfactors and that were mutated into their HotAldO counterparts to explore their effect on thermostability

MC1061 and TOP10 cells was extremely low under all conditions tested. As it is known that soluble expression levels can be boosted by fusing a protein of interest to the Cterminus of maltose binding protein (MBP) (Stevens 2000), we constructed the expression vector pBADmHAG. Fusion of MBP to the N-terminus of the HotAldO gene did not have any visible effects on the expression level. Due to the fact that satisfactory recombinant protein expression in heterologous systems is often thwarted by divergent codon usage, a synthetic HotAldO gene was obtained, which was codon optimized for expression in E. coli (Maertens et al. 2010). Cloning of this gene into the pBAD and pBAD-MBP expression vectors yielded pBADHAS and pBADmHAS. Expression of the codon optimized HotAldO gene was only 
marginally better than the wild-type gene, but by expressing the protein in TOP10 cells using the expression vector pBADHAS, in which the protein was fused to a Cterminal $6 \mathrm{xHis}$ tag, approximately $2.5 \mathrm{mg}$ of pure protein could be obtained from $1 \mathrm{~L}$ of culture broth using a single $\mathrm{Ni}^{2+}$-NTA agarose chromatography step under native conditions. SDS-PAGE analysis revealed that purified HotAldO runs as a single band at about $47 \mathrm{kDa}$, which corresponds well with the calculated mass of $46.8 \mathrm{kDa}$ (including FAD). After incubation in 5\% (v/v) acetic acid and visualization under UV light, the respective protein band is clearly fluorescent (Online Resource 1), indicative of a covalently bound flavin cofactor (Heuts et al. 2007; Fraaije et al. 1997). Size exclusion chromatography was used to study the oligomeric state of 6xHis-tag purified HotAldO under native conditions and revealed that the protein is a monomer in solution, showing exactly the same elution volume as $S$. coelicolor AldO (Heuts et al. 2007) (Online Resource 2).

The absorption spectrum of HotAldO (Online Resource 1) is very similar to that of AldO (Heuts et al. 2007); it has two absorption maxima at 350 and $450 \mathrm{~nm}$, characteristic for an oxidized flavin cofactor, and shoulders at 370,425 and $475 \mathrm{~nm}$. The absorption maximum at $350 \mathrm{~nm}$ is at a relatively low wavelength, a typical feature of histidylbound flavin cofactors (de Jong et al. 1992). Upon unfolding of the protein by SDS, the absorption maxima at 350 and $450 \mathrm{~nm}$ decrease slightly in intensity and shift slightly to lower wavelengths (Online Resource 1). Such a hypsochromic shift, compared to free FAD or FMN, is characteristic of $8 \alpha$-substituted flavin (Singer and Edmondson 1980), like found in AldO. Assuming that the absorption spectrum of the unfolded protein can be compared to that of free FAD $\left(\varepsilon_{450 \mathrm{~nm}}=11.3 \mathrm{mM}^{-1} \mathrm{~cm}^{-1}\right)$ (de Jong et al. 1992), a molar extinction coefficient of $12.5 \mathrm{mM}^{-1} \mathrm{~cm}^{-1}$ (at $450 \mathrm{~nm}$ ) can be calculated for the native enzyme. Comparing the spectral characteristics of AldO (Heuts et al. 2007) and HotAldO reveals a large degree of similarity between the two proteins and implies that the flavin cofactor in HotAldO is in a similar microenvironment and covalently bound to the protein backbone via an $8 \alpha-N$-histidyl linkage. The presence of a covalent histidyl-linked FAD is supported by a model constructed of HotAldO; this revealed that His46 in HotAldO is in a similar position and orientation to the residue in AldO responsible for anchoring FAD, His46 (Fig. 2) (Forneris et al. 2008).

\section{Steady-state catalytic properties of HotAldO}

Inspection of the ClustalW alignment of HotAldO and AldO (Fig. 1) revealed a remarkably complete degree of conservation of the active site residues that are involved in substrate binding and catalysis (Forneris et al. 2008). Closer analysis of the structural model shows that these residues in

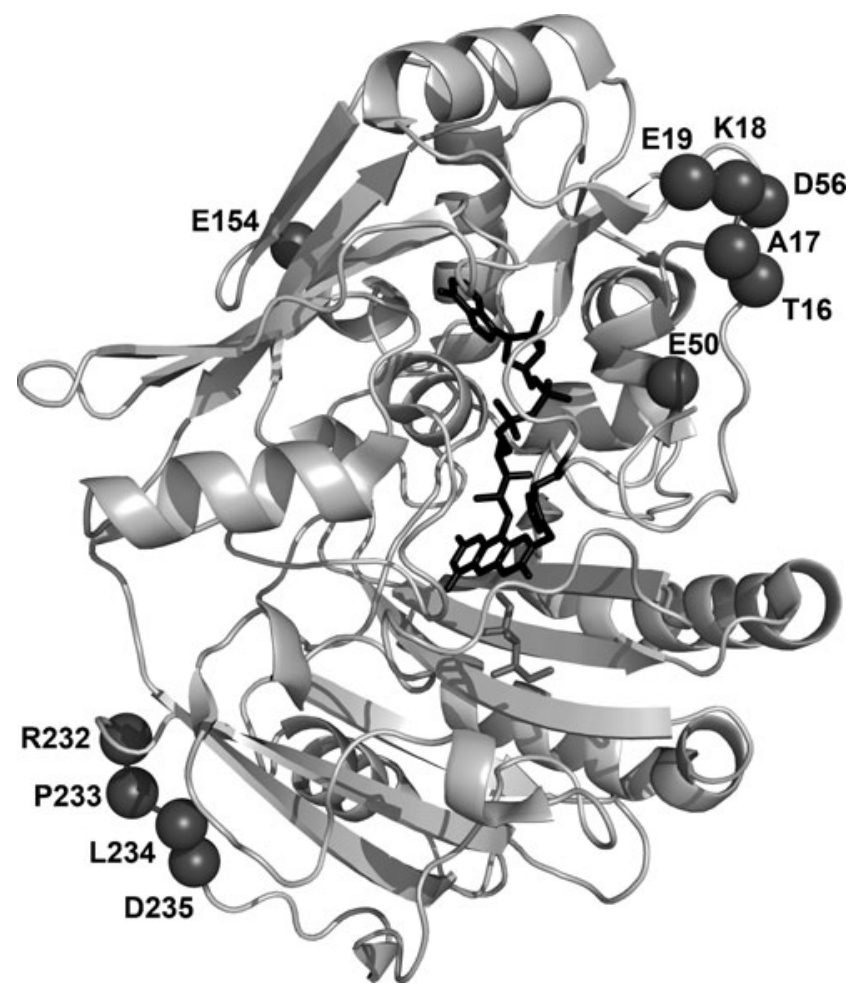

Fig. 2 Crystal structure of AldO with xylitol bound (PDB id: 2VFS) showing the location of residues (dark spheres) that were mutated into their HotAldO counterparts in order to explore their effect on enzyme thermostability. The His 46 bound FAD cofactor is shown as black sticks; xylitol is shown as dark gray sticks

HotAldO all have a similar position and orientation as their AldO counterparts. As a result, we anticipated that the substrate scope of HotAldO would be similar to that of AldO, acting on a broad range of aliphatic and aromatic diols and polyols, and preferring the C5 and C6 alditols xylitol and sorbitol (van Hellemond et al. 2009). Table 1 details the steady-state kinetic parameters for a selection of HotAldO substrates and reveals that the activity profile of this enzyme towards the substrates tested is remarkably similar to that of AldO. The 5-carbon alditol xylitol is the preferred substrate, and increasing or reducing the alditol chain length only serves to reduce the substrate specificity as evidenced by a higher $K_{\mathrm{M}}$ value for the 3 carbon polyol glycerol and the 6 carbon alditol sorbitol. In agreement with the fact that the enzyme originates from a thermophilic organism and that the experiments were carried out at mesophilic temperatures, the measured $k_{\text {cat }}$ values are nearly all significantly (between $70 \%$ and $90 \%$ ) lower than those of AldO. The kinetic behavior of HotAldO is the same as AldO for all of the substrates tested, with the exception of glycerol. Repeated experiments revealed significant substrate inhibition at high glycerol concentrations $(>500 \mathrm{mM})$, which is something that was not observed for AldO. Using the modified Michaelis-Menten rate equation for substrate inhibition (Cornish-Bowden 1995), an apparent inhibition 
Table 1 Steady-state kinetic parameters for recombinant HotAldO and AldO. The kinetic parameters of both enzymes were measured at $25{ }^{\circ} \mathrm{C}$ in $50 \mathrm{mM}$ potassium phosphate buffer $(\mathrm{pH}$ 7.5). The kinetic parameters given for AldO have been described elsewhere (Heuts et al. 2007; van Hellemond et al. 2009)

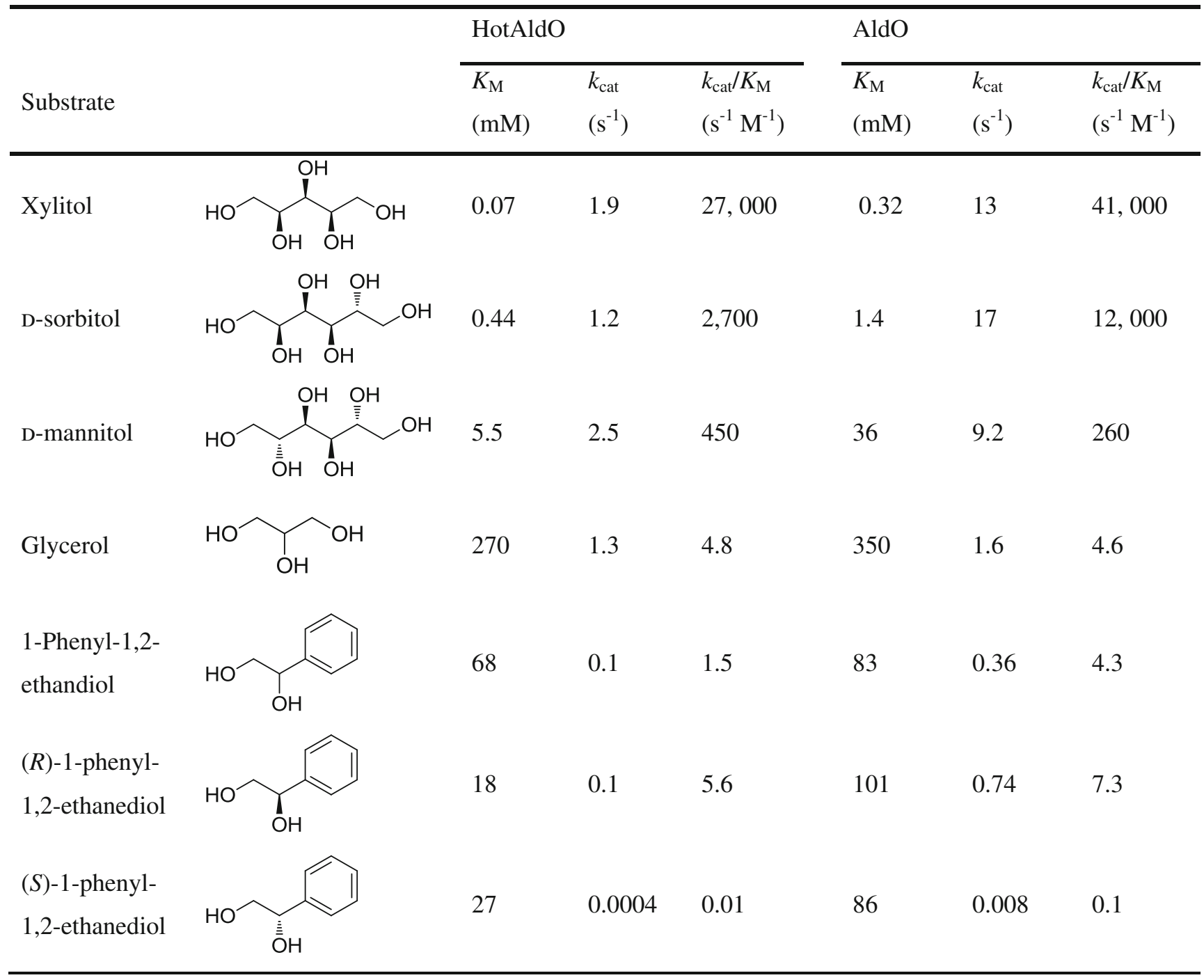

constant $\left(K_{\mathrm{si}}\right)$ of $1,500 \mathrm{mM}$ was calculated. However, as the inhibition was observed at such high glycerol concentrations (>4\%), viscosity based effects cannot be ruled out (Pocker and Janjic 1987). To offset this reduction in rate and by supporting the fact that proteins from thermophilic organisms are often more rigid than their mesophilic counterparts (Vihinen 1987), the substrate specificity of HotAldO for the substrates tested is slightly better than that of AldO, as evidenced by the fact that the Michaelis constants for HotAldO are mostly $65-85 \%$ lower than their AldO counterparts.

With $10 \mathrm{mM}$ xylitol as substrate, the $\mathrm{pH}$ optimum for enzyme activity was determined. Like AldO (van Hellemond et al. 2009), purified HotAldO has a broad $\mathrm{pH}$ optimum; more than $80 \%$ of its maximum activity is found between pH 6 and 9. HotAldO is reasonably active at acidic pHs; at
$\mathrm{pH} 4.5$, it retains $20 \%$ of its maximum activity. This compares favorably to AldO, which is inactive at and below $\mathrm{pH}$ 5.

As it is known that AldO can selectively oxidize the $R$ enantiomer of several (aromatic) diols (van Hellemond et al. 2009), we were intrigued if HotAldO exhibits the same enantioselectivity. For this reason, we measured the steady-state kinetic parameters of HotAldO with $(R)$-, $(S)$-, and racemic 1-phenyl-1,2-ethanediol. A similar trend was observed as that for AldO (Table 1), but due to the improved selectivity of HotAldO for the $R$ enantiomer, an $E$ value of 375 was calculated from the ratio between the specificity constants $\left(k_{\text {cat }} / K_{\mathrm{m}}\right)$ compared to an $E$ value of only 74 for AldO (van Hellemond et al. 2009), highlighting HotAldO's potential as an enantioselective biocatalyst. The notion that the mechanism of stereoselectivity is conserved between 
AldO and HotAldO is confirmed by the observation that the 6 carbon alditol D-mannitol is a worse substrate than the related compound D-sorbitol, as evidenced by the ten-fold higher $K_{\mathrm{m}}$ value, a feature that the crystal structure of AldO revealed to be caused by the orientation of the secondary hydroxyl moiety of the substrate with respect to the imidazole ring of His343 (Forneris et al. 2008).

The redox state of HotAldO during steady-state catalysis was determined by monitoring the flavin absorbance with stopped-flow spectroscopy. After mixing $250 \mu \mathrm{M} \mathrm{O} \mathrm{O}_{2}$, $15 \mathrm{mM}$ xylitol and $10 \mu \mathrm{M}$ HotAldO at $25^{\circ} \mathrm{C}$, a fast-within $100 \mathrm{~ms}$ - decrease in the absorbance at $450 \mathrm{~nm}$ was observed before the steady-state phase was reached. The steady-state phase lasted for about $10 \mathrm{~s}$, which agrees with the calculated $k_{\text {cat }}$ value, and was followed by a rapid and complete reduction of the flavin due to the excess of xylitol. Under steady-state conditions, $20 \%$ of the flavin is in the oxidized form, a much lower value than the $32 \%$ calculated for AldO (Heuts et al. 2007) and in agreement with the finding that the reoxidation rate of HotAldO is significantly lower than that of AldO (see 'Pre-steady-state kinetic analysis').

HotAldO is a highly thermostable enzyme

As HotAldO originates from a thermophilic organism $(A$. cellulolyticus $\mathrm{OGT}=55{ }^{\circ} \mathrm{C}$ ), we anticipated that it would function as a thermostable oxidase. Unfolding experiments performed using the ThermoFAD method, which measures the increase in flavin fluorescence as the protein denatures (Forneris et al. 2009), revealed that the $T_{\mathrm{m}}$ of HotAldO is $84{ }^{\circ} \mathrm{C}$, significantly higher than the $61{ }^{\circ} \mathrm{C}$ measured for AldO. Thermostability measurements were carried out on HotAldO and AldO to further characterize the thermal stability of these two oxidases. By incubating samples of the enzymes at various temperatures and measuring the activity at regular intervals, the enzyme activity half-life was calculated at three different temperatures. These measurements revealed that HotAldO has an impressive thermostability; at $60{ }^{\circ} \mathrm{C}$, its activity half-life, $t_{1 / 2} 60{ }^{\circ} \mathrm{C}$, is a staggering $1,700 \mathrm{~min}(28 \mathrm{~h}$ and $20 \mathrm{~min}$ ) compared to the $1.1 \mathrm{~min}$ of AldO. At $75^{\circ} \mathrm{C}$ and $80^{\circ} \mathrm{C}$, the thermal inactivation of AldO was too rapid to enable determination of the activity halflife, while that of HotAldO was still a respectable 111.8 and $2.0 \mathrm{~min}$, respectively. The thermostability data support the unfolding temperatures calculated by ThermoFAD; at temperatures close to the $T_{\mathrm{m}}$, the activity half-life of both enzymes is mere minutes $\left(T_{\mathrm{m}} \mathrm{AldO}=61{ }^{\circ} \mathrm{C}, t_{1 / 2} 60{ }^{\circ} \mathrm{C}=\right.$ $1.1 \mathrm{~min} ; T_{\mathrm{m}}$ HotAldO $=84{ }^{\circ} \mathrm{C}, t_{1 / 2} 80{ }^{\circ} \mathrm{C}=2.0 \mathrm{~min}$ ). The optimum temperature for initial activity was determined for both enzymes and also found to match the $T_{\mathrm{m}}$ values quite well: $55{ }^{\circ} \mathrm{C}$ for $\mathrm{AldO}$ and $80{ }^{\circ} \mathrm{C}$ for HotAldO. Figure 3 shows the residual activity of both AldO and HotAldO after

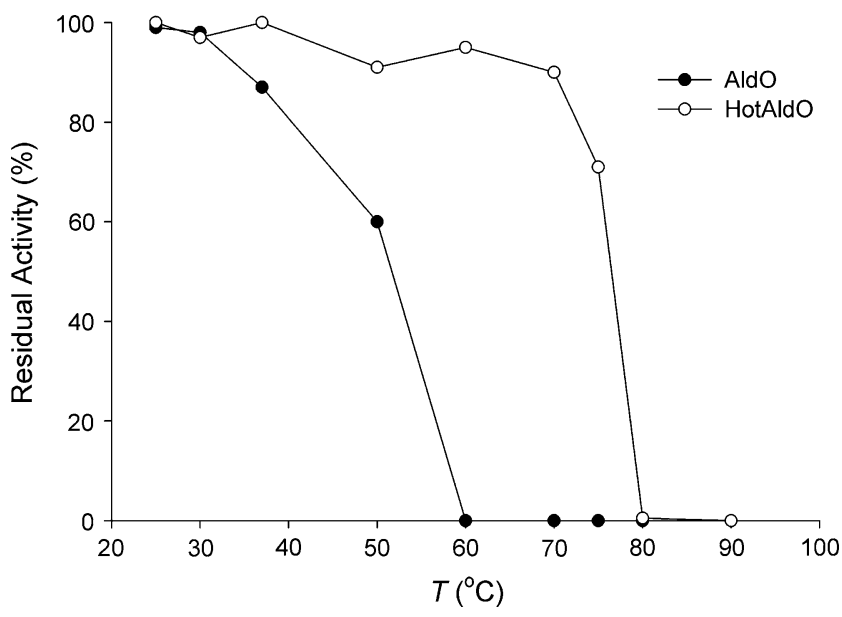

Fig. 3 Thermostability of $S$. coelicolor AldO and A. cellulolyticus HotAldO shown by residual activity curves. Oxidase activity with xylitol as substrate was measured after enzyme solutions had been incubated at various temperatures $\left(25-90{ }^{\circ} \mathrm{C}\right)$ for $1 \mathrm{~h}$

incubation at different temperatures for $1 \mathrm{~h}$. From this graph, it is immediately clear that HotAldO is an extremely thermostable oxidase when compared to its mesophilic counterpart AldO.

Pre-steady-state kinetic analysis

To study the subtle mechanistic differences between AldO and HotAldO in more detail, we decided to investigate the pre-steady-state kinetics of HotAldO with xylitol as substrate. Using a stopped-flow instrument equipped with diode-array detection for spectral scans and a photomultiplier tube for single wavelength measurements, we could follow the spectral changes of the covalently linked flavin cofactor during the reductive and oxidative half-reactions (measured separately). As the catalytic efficiency of HotAldO with xylitol is significantly lower than that of AldO with xylitol, we set out to determine whether the reductive or oxidative half-reaction is rate limiting. The reductive half-reaction of HotAldO was monitored by anaerobically mixing the enzyme with different amounts of xylitol, as described previously (Heuts et al. 2007). From the resulting spectral data, a hyperbolic dependency of the reduction rate on the xylitol concentration was observed. Fitting of this data yielded a reduction rate constant $\left(k_{\text {red }}\right)$ of $53 \mathrm{~s}^{-1}$ and a $K_{\mathrm{d}}$ of $2.0 \mathrm{mM}$. While significantly slower than the reduction rate of AldO (99 $\mathrm{s}^{-1}$ (Heuts et al. 2007) the reduction rate does not appear to be the rate-limiting step in the catalytic cycle of HotAldO.

The oxidative half-reaction of HotAldO was measured by mixing reduced enzyme with different amounts of molecular oxygen and following the reoxidation of the flavin cofactor at $452 \mathrm{~nm}$. After complete reduction of HotAldO by three equivalents of xylitol, mixing with molecular oxygen 
revealed relatively rapid reoxidation of the flavin cofactor. From the linear relation between $k_{\mathrm{obs}}$ and $\left[\mathrm{O}_{2}\right]$, a bimolecular rate constant ( $k_{\mathrm{ox}, 1}$; Heuts et al. 2007) of $4.4 \times 10^{4} \mathrm{M}^{-1}$ $\mathrm{s}^{-1}$ was calculated. While this rate constant is lower than the $1.7 \times 10^{5} \mathrm{M}^{-1} \mathrm{~s}^{-1}$ found for AldO (Heuts et al. 2007), it does not explain the lowered catalytic efficiency of HotAldO for xylitol. At ambient $\mathrm{O}_{2}$ concentrations $(250 \mu \mathrm{M})$, a $k_{\text {obs }}$ for reoxidation of $11 \mathrm{~s}^{-1}$ was observed, highlighting the fact that the oxidative half-reaction is, like the reductive halfreaction, not the rate-limiting step in the catalytic cycle of HotAldO with xylitol. This finding is supported by the fact that the 'oxygen gatekeeper' residue (Leferink et al. 2009) in HotAldO is a glycine (Gly101; Ala105 in AldO; Fig. 1), indicative of optimal oxidase oxygen reactivity (Baron et al. 2009). Hence, more subtle effects such as substrate binding and product release are likely to determine the rate-limiting step.

\section{Reverse engineering HotAldO thermostability into AldO}

Due to the high degree of functional and sequence homology between AldO and HotAldO, we wondered if it would be possible to engineer HotAldO's thermostability into its less stable counterpart, AldO. Due to the extremely high expression levels of AldO (up to $350 \mathrm{mg} \mathrm{L}^{-1}$ culture; Heuts et al. 2007) and good catalytic efficiency, this was a very attractive possibility, especially in view of AldO's potential for practical applications. Several high-resolution crystal structures of AldO are available (Forneris et al. 2008), and as it is known that residues with high B-factors contribute to protein instability (Vihinen 1987), we decided to mutate those residues in AldO that have a very high B-factor; an approach that has been employed successfully in the past, most notably to improve the thermostability of a lipase from Bacillus subtilis (LipA) (Reetz et al. 2006). By analyzing the 1.6- $\AA$ crystal structure of AldO complexed with xylitol (PDB id: 2VFS), we identified three regions on the surface of the protein that possessed relatively high B-factors: residues 16-19, 56 and 232-235 (Fig. 2). Looking at the highly thermostable oxidase HotAldO for inspiration, we inspected the sequence alignment of AldO and HotAldO (Fig. 1) and identified the HotAldO residues that corresponded to the AldO residues with high B-factors. Consequently, AldO mutants were constructed by site-directed mutagenesis (Table 2), whereby the AldO residue with a high B-factor was replaced by its HotAldO counterpart. As HotAldO is a much more thermostable enzyme, we hypothesized that these residues would improve the thermal stability of AldO.

Inspection of the sequence alignment of $\mathrm{AldO}$ and HotAldO also revealed that HotAldO contains a high number of prolines compared to AldO ( 36 and 28, respectively). As it is known that prolines confer rigidity to a protein backbone and can bring a region into $\alpha$-helix configuration, thereby
Table 2 Measured $T_{\mathrm{m}}$ and predicted $\Delta \Delta \mathrm{G}^{\mathrm{FOLD}}$ of alditol oxidase (AldO) thermostability mutants. Unfolding temperatures $\left(T_{\mathrm{m}}\right)$ were determined using a modification of the ThermoFAD method, as described in 'Materials and methods'. In bold are the $\Delta \Delta \mathrm{G}^{\mathrm{FOLD}}$ energies that are, taking the error into account, significant (error margin was taken as linearly dependent on the number of mutations)

\begin{tabular}{|c|c|c|c|}
\hline \multirow[t]{2}{*}{ Variant } & \multirow[t]{2}{*}{$T_{\mathrm{m}}\left({ }^{\circ} \mathrm{C}\right)$} & \multicolumn{2}{|c|}{$\begin{array}{l}\Delta \Delta \mathrm{G}^{\mathrm{FOLD}}\left(\mathrm{kJ} \mathrm{mol}^{-1}\right) \\
\text { predicted by }\end{array}$} \\
\hline & & FoldX & Rosetta \\
\hline Wild type & 61.0 & 0 & 0 \\
\hline T16R/A17P & 60.8 & 1.5 & 0.9 \\
\hline K18R/E19R & 61.0 & 1.2 & 1.2 \\
\hline T16R/A17P/K18R/G19R & 60.0 & -3.4 & 2.3 \\
\hline E50P & 59.9 & 2.3 & -2.8 \\
\hline Asp56 deletion mutant & 58.0 & $\mathrm{ND}^{\mathrm{a}}$ & $\mathrm{ND}^{\mathrm{a}}$ \\
\hline E154P & 60.7 & -5.5 & -5.3 \\
\hline $\mathrm{R} 232 \mathrm{~A} / \mathrm{P} 233 \mathrm{G}$ & 58.8 & 12.6 & 13.4 \\
\hline L234R/D235P & 60.5 & 6.4 & 24.8 \\
\hline R232A/P233G/L234R/D235P & 58.0 & 19.1 & 38.0 \\
\hline
\end{tabular}

ND: not determined

a For deletion mutants, the change in folding energy cannot be predicted reliably

having a positive effect on thermostability (Watanabe et al. 1994), two residues in AldO (Glu50 and Glu154; Table 2) were mutated into the corresponding HotAldO prolines (Figs. 1 and 2).

Due to the large number of mutants that needed to be tested, we designed a medium-throughput thermostability screen, based on measuring the unfolding temperature, $T_{\mathrm{m}}$, of the AldO mutants in desalted cell extracts using the ThermoFAD method. The comparison between two homologous enzymes carried out in this study supports other studies (Ericsson et al. 2006; Matulis et al. 2005) that the $T_{\mathrm{m}}$ of a protein is a good measure of its thermostability. As the soluble expression of AldO is high in E. coli $\mathrm{MC} 1061$ (roughly $20 \%$ of total soluble protein; Heuts et al. 2007), it is not necessary to purify the protein to get accurate $T_{\mathrm{m}}$ data; ThermoFAD measurements are possible on cleared cell extracts. This approach was validated by measuring the $T_{\mathrm{m}}$ of wild-type AldO using purified protein and cell extracts. Cell extracts were desalted before measuring the $T_{\mathrm{m}}$ to reduce the background fluorescence present in the form of free FAD. Table 2 details the $T_{\mathrm{m}}$ determined for wild-type AldO in soluble extracts; the value is identical to the value when analyzing purified protein: $61{ }^{\circ} \mathrm{C}$ (see 'HotAldO is a highly thermostable enzyme'). While the temperature versus raw fluorescence traces for the two samples (pure protein and soluble cell extracts) are not identical, the maximum of the derivative of these sigmoidal curves is found at the same temperature and is highly reproducible over multiple 
samples (data not shown). Before assaying the AldO mutants for their unfolding temperature, we determined if the soluble expression level and degree of covalent cofactor incorporation were unchanged compared to wild type. SDSPAGE analysis and staining for cofactor fluorescence revealed that all nine mutants were expressed in E. coli MC1061 and contained covalently bound FAD, both at levels comparable to wild-type AldO. Activity with $10 \mathrm{mM}$ xylitol as substrate was also similar to wild-type AldO (data not shown). ThermoFAD measurements to calculate the unfolding temperature of the AldO mutants in cell free extracts did not reveal any significant increase in the $T_{\mathrm{m}}$, and hence thermostability, for any of the mutants tested. For all mutants tested, the $T_{\mathrm{m}}$ was the same or slightly lower than the wild-type variant. The largest negative effect was the $3{ }^{\circ} \mathrm{C}$ decrease in $T_{\mathrm{m}}$ caused by the D56 deletion and R232A/ $\mathrm{P} 233 \mathrm{G} / \mathrm{L} 234 \mathrm{R} / \mathrm{D} 235 \mathrm{P}$ mutations. On the whole, it is interesting to note that AldO is a relatively robust enzyme, being able to withstand a large number of mutations with apparently no or marginal effects on its expression, activity and stability. In this case, however, we must conclude that replacing residues in AldO that have a high B-factor with corresponding residues from its thermostable counterpart HotAldO did not yield a more thermostable AldO mutant.

Computational analysis of thermostability mutants

To explain why the mutations had a slightly negative or negligible effect on the melting temperature, the change in folding energy by the mutations was calculated via both FoldX and Rosetta software (Table 2). For most of the variants, the predicted change in folding energy is within error identical to zero, and all of these variants also have a melting temperature that differs maximally $1{ }^{\circ} \mathrm{C}$ from the WT. For the E154P, a small but significant improvement in folding energy is predicted, which is not reflected in its melting temperature, which is within $0.5{ }^{\circ} \mathrm{C}$ of the wildtype protein. For the R232A/P233G and R232A/P233G/ L234R/D234P variants, both Rosetta and FoldX predict that the $\Delta \mathrm{G}^{\mathrm{FOLD}}$ is significantly worse than that for WT, which is in line with the $2-3{ }^{\circ} \mathrm{C}$ lower melting temperatures of these variants. Thus, the experimentally determined melting temperatures and the calculated changes in folding energy agree reasonably. For the Asp56 deletion mutant, the loop in which it is located is predicted to change conformation due to the mutation, which could have resulted in strain, explaining the $3{ }^{\circ} \mathrm{C}$ lower melting temperature. For the R232A/ $\mathrm{P} 233 \mathrm{G}$ and $\mathrm{R} 232 \mathrm{~A} / \mathrm{P} 233 \mathrm{G} / \mathrm{L} 234 \mathrm{R} / \mathrm{D} 234 \mathrm{P}$ variants, less damaging problems were found, most notably a loss of hydrophobic interactions by the L234R mutation that could (partially) explain the loss of folding free energy and corresponding reduction in melting temperature.
The original reason to mutate at the chosen positions was their high B-factor, which suggests that it is a critical spot in the protein. Since the experimental results indicated that the $T_{\mathrm{m}}$ was only moderately affected, MD simulations were carried out to exclude that the relatively high B-factors in these regions were due to crystal packing interactions. The RMSF from an MD simulation was similar for the protein in solution and the X-ray structure (Online Resource 3), which indicates that the protein flexibility of free protein in solution is similar to that of the X-ray structure, which was earlier used to choose positions to mutate. Specifically, in both X-ray structure and simulations, the N-terminus is the most mobile part of the enzyme, while the region around residue 230 , which was targeted by the mutations, is the second most mobile part. Also, the region around residue 30 is one of the most mobile parts in the protein structure during the MD simulations.

\section{Discussion}

Flavoprotein oxidases represent a versatile class of oxidative biocatalysts, but their availability is limited; at present, only a handful have been fully characterized (van Hellemond et al. 2006), and most are of fungal origin and mesophilic in character. In this paper, we detail the search for a thermophilic oxidase by searching the bacterial genome database for homologues of the well-studied S. coelicolor AldO, a member of the VAO family of flavoprotein oxidases. We identified two putative thermophilic oxidases in the genomes of the thermophiles Thermobifida fusca and $A$. cellulolyticus. Subsequent cloning and heterologous expression in E. coli revealed that both proteins were covalent flavoproteins, as was expected from sequence analysis: both contained the distinguishing VAO family covalent-FAD motif (Fig. 1; Fraaije et al. 1998). As no oxidase substrate could be identified for the putative Thermobifida fusca oxidase, perhaps due to its rather low (31\%) sequence identity with $\mathrm{AldO}$, we continued with the characterization of the putative $A$. cellulolyticus oxidase, which we named HotAldO due to its thermophilic origin and its high homology (48\%) and overlap in substrate specificity to $S$. coelicolor AldO. The physiological function of HotAldO, as with most other oxidases, is unknown. Besides $S$. coelicolor AldO, several other homologues with high sequence identities (\%) have been identified in actinomycete genomes including Streptomyces sp. (55\%), Catenulispora acidiphila (54\%), Frankia sp. EuI1c (54\%), Verrucosispora maris (54\%), S. flavogriseus (53\%) and Kribbella flavida (50\%). The fact that AldO, HotAldO and the homologue XylOx (48\%) from Streptomyces sp. IKD472 (Yamashita et al. 2000) all act as oxidases, preferentially converting alditols, seems to indicate that the aforementioned organisms all 
harbor an alditol oxidase orthologue for some as yet unknown catabolic or anabolic route. Modification of some secondary metabolite is a realistic possibility; actinomycetes are well known for their ability to produce such compounds, which often contain polyol moieties (Mao et al. 1999). It is also possible that HotAldO is used by the organism in a catabolic route for alditol degradation. Inspection of the genome of A. cellulolyticus shows that the HotAldO gene is flanked by several genes involved in carbohydrate modifications and transport, including a major facilitator transporter, a glycosyl transferase protein, a carbohydrate kinase, a fructose-biphosphate aldolase and a DeoR family transcriptional regulator.

Obtaining sufficient yield of heterologously expressed HotAldO proved to be problematic. Fusing the protein to MBP, which helped to boost the expression of AldO significantly (Heuts et al. 2007), did not have any visible effects on HotAldO expression levels. The protein was finally isolated by expressing a synthetic gene, codon-optimized for $E$. coli. While codon optimization often has a beneficial effect on the yields of heterologously expressed protein (Maertens et al. 2010), in this case, the improvement was marginal; only $2.5 \mathrm{mg}$ of pure protein was obtained per liter of culture. It should be noted that the success of codon optimization in improving the expression is extremely dependent on the optimization strategy employed; recent developments in this field seem to suggest that paradigms that have long been dogmatically adhered to have little empirical basis (Welch et al. 2009).

The most unique feature of HotAldO is its thermostability. Its high $T_{\mathrm{m}}\left(84^{\circ} \mathrm{C}\right)$ and long activity half-life at elevated temperatures $\left(t_{1 / 2} 60{ }^{\circ} \mathrm{C}>24 \mathrm{~h}\right)$ make it the most thermostable carbohydrate oxidase of bacterial origin described to date. It should be noted that relatively few thermostable flavoprotein oxidases are known; the most striking examples include pyranose oxidase (P2Ox), a carbohydrate oxidase recently isolated from the model white rot fungi Phanerochaete chrysosporium (Pisanelli et al. 2009) with a $T_{\mathrm{m}}$ of $75.4{ }^{\circ} \mathrm{C}$ and a $t_{1 / 2} 50{ }^{\circ} \mathrm{C}>24 \mathrm{~h}$ (Salaheddin et al. 2010), and cholesterol oxidase (CHOLOX) from Chromobacterium sp. DS-1, which holds the oxidase thermostability record, retaining $90 \%$ of its original activity after incubation for $60 \mathrm{~min}$ at $80{ }^{\circ} \mathrm{C}$ (Doukyu et al. 2008). Due to the high homology to its mesophilic counterpart AldO, the thermostability of HotAldO is even more striking. As no crystal structure of HotAldO is available yet, we should be careful about drawing any conclusions about the structural and physical basis for this increased thermostability. Having a crystal structure is no panacea, however, as both in the case of CHOLOX and more thermostable mutants of Trametes multicolor $\mathrm{P} 2 \mathrm{Ox}$, high-quality crystal structures did not reveal the structural basis for the high thermostability (Sagermann et al. 2010; Spadiut et al. 2009).
The relatively larger number of charged residues of HotAldO (Online Resource 4) is in agreement with the observation that salt-bridge networks are often responsible for thermostabilization of proteins (Karshikoff and Ladenstein 2001; Missimer et al. 2007). The relative amino acid content of the proteins is unlikely to be solely responsible for thermostability, however, as the trends observed here for the AldO-HotAldO pair are only in partial agreement with the trends observed elsewhere for a $>100$ protein set of mesophilic and thermophilic protein pairs (Greaves and Warwicker 2007). For the residues Pro, Arg, Ala, Ile, Gly and Asp, the trend observed here agrees with the trends observed for a much larger set, while the relative changes observed for Val, Leu and Glu (which should increase, not stay constant) do not agree. It is impossible to currently identify the mutations responsible for the higher thermostability of HotAldO since the sequence identity is only $48 \%$, while far fewer mutations can potentially bridge the $23{ }^{\circ} \mathrm{C}$ gap in melting temperature, as shown by protein engineering carried out on other enzymes (Reetz et al. 2006; Eijsink et al. 2004).

The substrate specificity of HotAldO is remarkably similar to that of AldO. The same range of polyols is converted, with alditols xylitol and sorbitol being preferred. This lends support to the notion that both enzymes have a similar functional role in their parent organisms. The high degree of conservation between the active-site residues of AldO and HotAldO that are involved in substrate recognition and binding (Fig. 1) and the intricate network of hydrogen bonds that are involved in the binding of xylitol (Forneris et al. 2008) also seem to suggest that an alditol highly similar to xylitol is probably the physiological substrate of these enzymes in vivo; other substrates simply do not fit as well in the alditol oxidase active site. Across the board, the catalytic rates of the substrates tested for HotAldO are lower than the corresponding rates for $\mathrm{AldO}$, whereas the substrate recognition, as evidenced by the lower $K_{\mathrm{m}}$ values, is slightly better for HotAldO than that for AldO. This is in line with the finding that thermophilic enzymes are more rigid than their mesophilic counterparts and, consequently, have slower catalytic rates at ambient temperatures. A more rigid structure, however, improves substrate recognition, allowing for tighter substrate binding and lower $K_{\mathrm{m}}$ values. The enantioselectivity of HotAldO towards $(R)$ - (aromatic) diols is also conserved compared to AldO, as evidenced by the selective oxidation of $(R)$-1-phenyl-1,2-enthanediol. Again, probably due to its thermophilic nature and more rigid structure, it displays an enhanced selectivity towards the $(R)$-enantiomer compared to AldO, which results in a higher $E$-value for this substrate.

We performed pre-steady-state kinetic analysis of the reductive and oxidative half-reactions separately in order to see if we could identify a rate-limiting step that would 
explain the lowered catalytic efficiency of HotAldO compared to AldO. While both half-reactions of HotAldO had lower rates than AldO, neither could explain the lower overall catalytic rate of HotAldO. Probably, more subtle effects involving substrate binding and product release are at play. It is interesting to note that the reduced oxygen reactivity is in line with molecular dynamics simulations performed on the oxygen diffusion through the protein matrix of AldO (Baron et al. 2009). According to this study, diffusion of molecular oxygen through the protein matrix to the reduced flavin in the active site occurs through discrete, funnel-like pathways, which are conserved at higher temperatures. Thus, the overall rate of oxygen reactivity is governed by the overall flexibility of the protein and the movement of local side chains (partially) blocking the oxygen funnels.

Inspired by earlier studies (Reetz et al. 2006), we attempted to reverse engineer the thermostability of HotAldO into its mesophilic counterpart AldO by replacing those residues with high B-factors in AldO with their HotAldO counterparts, generating seven AldO variants by site-directed mutagenesis. Two further mutants were made; replacing AldO residues with corresponding HotAldO prolines (Fig. 1, Table 2) as such mutants can have beneficial effects on the thermostability (Watanabe et al. 1994). Although all nine mutants were overexpressed, soluble, contained covalently bound flavin and were active with xylitol, unfolding experiments revealed that none of the AldO mutants was more thermostable than the wild-type variant. Due to the large number of mutant enzymes that had to be assayed for unfolding temperatures, we successfully pioneered a variation of the ThermoFAD method for determining the $T_{\mathrm{m}}$ of flavoproteins where we could obtain accurate $T_{\mathrm{m}}$ values from direct measurement of cell extracts.

The calculations carried out with FoldX and Rosetta confirmed that the variants that displayed the largest thermostability loss as evidenced by reduction in $T_{\mathrm{m}}$ were less stable than wild-type AldO. Inspection of the predicted 3Dstructures indicated that this was due to local strain or packing problems such as loss of hydrophobic interactions. The relatively small $\left(3{ }^{\circ} \mathrm{C}\right)$ decreases in melting temperature by the quite drastic Asp56 deletion mutation and the R232A/P233G/L234R/D235P four-fold mutation may indicate that these residues are not in a so-called weak spot of the protein that is more sensitive for unfolding (Eijsink et al. 2004), although the higher B-factors had suggested it to be. It should be noted that the approach followed here was relatively simplistic and that it is very possible that the mutations made were simply not the correct ones required to improve thermostability. It could be envisaged that performing saturation mutagenesis at these positions would yield a more thermostable variant, an approach successfully employed by Reetz et al. (2006). It is clear from our study, however, that care should be exercised when using B-factors alone to design more thermostable protein variants.

Taken together, our data reveal that we have successfully identified a highly thermostable alditol oxidase from a thermophilic actinomycete, once again highlighting the biocatalytic potential of such heat-loving organisms. The biotechnological relevance of AldO has been studied and highlighted previously (van Hellemond et al. 2009), but with the discovery here of its thermophilic counterpart HotAldO, we have a new 'prodigal son' alditol oxidase, one that has a highly similar substrate specificity, enantioselectivity and catalytic efficiency but a vastly improved thermostability.

Acknowledgements This research is supported by the Dutch Technology Foundation STW (Grant number: GBC.7726), applied science division of NWO and the Technology Program of the Ministry of Economic Affairs.

Open Access This article is distributed under the terms of the Creative Commons Attribution Noncommercial License which permits any noncommercial use, distribution, and reproduction in any medium, provided the original author(s) and source are credited.

\section{References}

Bankar SB, Bule MV, Singhal RS, Ananthanarayan L (2009) Glucose oxidase - an overview. Biotechnol Adv 27:489-501

Barabote RD, Xie G, Leu DH, Normand P, Necsulea A, Daubin V, Medigue C, Adney WS, Xu XC, Lapidus A, Parales RE, Detter C, Pujic P, Bruce D, Lavire C, Challacombe JF, Brettin TS, Berry AM (2009) Complete genome of the cellulolytic thermophile Acidothermus cellulolyticus 11B provides insights into its ecophysiological and evolutionary adaptations. Genome Res 19:1033-1043

Baron R, Riley C, Chenprakhon P, Thotsaporn K, Winter RT, Alfieri A, Forneris F, van Berkel WJH, Chaiyen P, Fraaije MW, Mattevi A, McCammon JA (2009) Multiple pathways guide oxygen diffusion into flavoenzyme active sites. Proc Natl Acad Sci U S A 106:1060310608

Casadaban MJ, Cohen SN (1980) Analysis of gene control signals by DNA fusion and cloning in Escherichia coli. J Mol Biol 138:179207

Cornish-Bowden A (1995) Fundamentals of enzyme kinetics. Portland Press, London

de Jong E, van Berkel WJH, van der Zwan RP, de Bont JAM (1992) Purification and characterization of vanillyl-alcohol oxidase from Penicillium simplicissimum - a novel aromatic alcohol oxidase containing covalently bound FAD. Eur J Biochem 208:651-657

Doukyu N, Shibata K, Ogino H, Sagermann M (2008) Purification and characterization of Chromobacterium sp DS-1 cholesterol oxidase with thermal, organic solvent, and detergent tolerance. Appl Microbiol Biotechnol 80:59-70

Eijsink VGH, Bjork A, Gaseidnes S, Sirevag R, Synstad B, van den Burg B, Vriend G (2004) Rational engineering of enzyme stability. J Biotechnol 113:105-120

Ericsson UB, Hallberg BM, DeTitta GT, Dekker N, Nordlund P (2006) Thermofluor-based high-throughput stability optimization of proteins for structural studies. Anal Biochem 357:289-298

Federico R, Angelini R, Ercolini L, Venturini G, Mattevi A, Ascenzi P (1997) Competitive inhibition of swine kidney copper amine 
oxidase by drugs: amiloride, clonidine, and gabexate mesylate. Biochem Biophys Res Commun 240:150-152

Forneris F, Heuts DP, Delvecchio M, Rovida S, Fraaije MW, Mattevi A (2008) Structural analysis of the catalytic mechanism and stereoselectivity in Streptomyces coelicolor alditol oxidase. Biochemistry 47:978-985

Forneris F, Orru R, Bonivento D, Chiarelli LR, Mattevi A (2009) ThermoFAD, a Thermofluor ${ }^{\circledR}$-adapted flavin ad hoc detection system for protein folding and ligand binding. FEBS J 276:2833-2840

Fraaije MW, Pikkemaat M, van Berkel WJH (1997) Enigmatic gratuitous induction of the covalent flavoprotein vanillyl-alcohol oxidase in Penicillium simplicissimum. Appl Environ Microbiol 63:435-439

Fraaije MW, van Berkel WJ, Benen JA, Visser J, Mattevi A (1998) A novel oxidoreductase family sharing a conserved FAD-binding domain. Trends Biochem Sci 23:206-207

Fraaije MW, Wu J, Heuts DPHM, van Hellemond EW, Spelberg JHL, Janssen DB (2005) Discovery of a thermostable Baeyer-Villiger monooxygenase by genome mining. Appl Microbiol Biotechnol $66: 393-400$

Greaves RB, Warwicker J (2007) Mechanisms for stabilisation and the maintenance of solubility in proteins from thermophiles. BMC Struct Biol 7:18

Guerois R, Nielsen JE, Serrano L (2002) Predicting changes in the stability of proteins and protein complexes: a study of more than 1000 mutations. J Mol Biol 320:369-387

Hess B, Bekker H, Berendsen HJC, Fraaije JGEM (1997) LINCS: a linear constraint solver for molecular simulations. J Comp Chem 18:1463-1472

Heuts DP, van Hellemond EW, Janssen DB, Fraaije MW (2007) Discovery, characterization, and kinetic analysis of an alditol oxidase from Streptomyces coelicolor. J Biol Chem 282:2028320291

Hollmann F, Arends IWCE, Buehler K, Schallmey A, Buhler B (2011) Enzyme-mediated oxidations for the chemist. Green Chem 13:226-265

Jin J, Mazon H, van den Heuvel RH, Janssen DB, Fraaije MW (2007) Discovery of a eugenol oxidase from Rhodococcus sp. strain RHA1. FEBS J 274:2311-2321

Karshikoff A, Ladenstein R (2001) Ion pairs and the thermotolerance of proteins from hyperthermophiles: a 'traffic rule' for hot roads. Trends Biochem Sci 26:550-556

Kellogg EH, Leaver-Fay A, Baker D (2011) Role of conformational sampling in computing mutation-induced changes in protein structure and stability. Proteins-Struct Funct Bioinform 79:830-838

Krieger E, Koraimann G, Vriend G (2002) Increasing the precision of comparative models with YASARA NOVA — a self-parameterizing force field. Proteins 47:393-402

Krieger E, Darden T, Nabuurs SB, Finkelstein A, Vriend G (2004) Making optimal use of empirical energy functions: force-field parameterization in crystal space. Proteins 57:678-683

Krieger E, Joo K, Lee J, Lee J, Raman S, Thompson J, Tyka M, Baker D, Karplus K (2009) Improving physical realism, stereochemistry, and side-chain accuracy in homology modeling: four approaches that performed well in CASP8. Proteins-Struct Funct Bioinform $77: 114-122$

Larkin MA, Blackshields G, Brown NP, Chenna R, McGettigan PA, McWilliam H, Valentin F, Wallace IM, Wilm A, Lopez R, Thompson JD, Gibson TJ, Higgins DG (2007) Clustal W and clustal X version 2.0. Bioinformatics 23:2947-2948

Leferink NGH, Fraaije MW, Joosten HJ, Schaap PJ, Mattevi A, van Berkel WJH (2009) Identification of a gatekeeper residue that prevents dehydrogenases from acting as oxidases. J Biol Chem 284:4392-4397

Liese A, Seelbach K (2006) Industrial biotransformations. Wiley$\mathrm{VCH}$, Weinheim
Lykidis A, Mavromatis K, Ivanova N, Anderson I, Land M, DiBartolo G, Martinez M, Lapidus A, Lucas S, Copeland A, Richardson P, Wilson DB, Kyrpides N (2007) Genome sequence and analysis of the soil cellulolytic actinomycete Thermobifida fusca YX. J Bacteriol 189:2477-2486

Maertens B, Spriestersbach A, von Groll U, Roth U, Kubicek J, Gerrits M, Graf M, Liss M, Daubert D, Wagner R, Schafer F (2010) Gene optimization mechanisms: a multi-gene study reveals a high success rate of full-length human proteins expressed in Escherichia coli. Protein Sci 19:1312-1326

Mao YQ, Varoglu M, Sherman DH (1999) Molecular characterization and analysis of the biosynthetic gene cluster for the antitumor antibiotic mitomycin C from Streptomyces lavendulae NRRL 2564. Chem Biol 6:251-263

Matulis D, Kranz JK, Salemme FR, Todd MJ (2005) Thermodynamic stability of carbonic anhydrase: measurements of binding affinity and stoichiometry using ThermoFluor. Biochemistry 44:52585266

Missimer JH, Steinmetz MO, Baron R, Winkler FK, Kammerer RA, Daura X, Van Gunsteren WF (2007) Configurational entropy elucidates the role of salt-bridge networks in protein thermostability. Protein Sci 16:1349-1359

Miyamoto S, Kollman PA (1992) SETTLE: an analytical version of the SHAKE and RATTLE algorithm for rigid water models. J Comp Chem 13:952-962

Mohagheghi A, Grohmann K, Himmel M, Leighton L, Updegraff DM (1986) Isolation and characterization of Acidothermus cellulolyticus gen. nov., sp. nov., a new genus of thermophilic, acidophilic, cellulolytic bacteria. Int J Syst Bacteriol 36:435-443

Nielsen M, Lundegaard C, Lund O, Petersen TN (2010) CPHmodels3.0-remote homology modeling using structure-guided sequence profiles. Nucleic Acids Res 38:W576-W581

Pantoliano MW, Petrella EC, Kwasnoski JD, Lobanov VS, Myslik J, Graf E, Carver T, Asel E, Springer BA, Lane P, Salemme FR (2001) High-density miniaturized thermal shift assays as a general strategy for drug discovery. J Biomol Screen 6:429-440

Pisanelli I, Kujawa M, Spadiut O, Kittl R, Halada P, Volc J, Mozuch MD, Kersten P, Haltrich D, Peterbauer C (2009) Pyranose 2-oxidase from Phanerochaete chrysosporium-expression in E. coli and biochemical characterization. J Biotechnol 142:97-106

Pocker Y, Janjic N (1987) Enzyme kinetics in solvents of increased viscosity-dynamic aspects of carbonic-anhydrase catalysis. Biochemistry 26:2597-2606

Pollard DJ, Woodley JM (2007) Biocatalysis for pharmaceutical intermediates: the future is now. Trends Biotechnol 25:66-73

Punniyamurthy T, Velusamy S, Iqbal J (2005) Recent advances in transition metal catalyzed oxidation of organic substrates with molecular oxygen. Chem Rev 105:2329-2363

Reetz MT, Carballeira JD, Vogel A (2006) Iterative saturation mutagenesis on the basis of B factors as a strategy for increasing protein thermostability. Angew Chem Int Ed 45:7745-7751

Sagermann M, Ohtaki A, Newton K, Doukyu N (2010) Structural characterization of the organic solvent-stable cholesterol oxidase from Chromobacterium sp DS-1. J Struct Biol 170:32-40

Sakon J, Adney WS, Himmel ME, Thomas SR, Karplus PA (1996) Crystal structure of thermostable family 5 endocellulase E1 from Acidothermus cellulolyticus in complex with cellotetraose. Biochemistry 35:10648-10660

Salaheddin C, Takakura Y, Tsunashima M, Stranzinger B, Spadiut O, Yamabhai M, Peterbauer CK, Haltrich D (2010) Characterisation of recombinant pyranose oxidase from the cultivated mycorrhizal basidiomycete Lyophyllum shimeji (hon-shimeji). Microbial Cell Factories 9:

Sheldon RA (2008) E factors, green chemistry and catalysis: an odyssey. Chem Commun 3352-3365 
Singer TP, Edmondson DE (1980) [36] Structure, properties, and determination of covalently bound flavins. In: Donald B. McCormick LDW (ed) Methods in enzymology. Academic Press, pp 253-264

Spadiut O, Leitner C, Salaheddin C, Varga B, Vertessy BG, Tan TC, Divne C, Haltrich D (2009) Improving thermostability and catalytic activity of pyranose 2-oxidase from Trametes multicolor by rational and semi-rational design. FEBS J 276:776-792

Stevens RC (2000) Design of high-throughput methods of protein production for structural biology. Structure 8:R177-R185

Studier FW, Moffatt BA (1986) Use of bacteriophage-T7 RNApolymerase to direct selective high-level expression of cloned genes. J Mol Biol 189:113-130

van Bloois E, Winter RT, Janssen DB, Fraaije MW (2009) Export of functional Streptomyces coelicolor alditol oxidase to the periplasm or cell surface of Escherichia coli and its application in whole-cell biocatalysis. Appl Microbiol Biotechnol 83:679-687

van Bloois E, Pazmino DET, Winter RT, Fraaije MW (2010) A robust and extracellular heme-containing peroxidase from Thermobifida fusca as prototype of a bacterial peroxidase superfamily. Appl Microbiol Biotechnol 86:1419-1430

van Bloois E, Winter RT, Kolmar H, Fraaije MW (2011) Decorating microbes: surface display of proteins on Escherichia coli. Trends Biotechnol 29:79-86

van Hellemond EW, Leferink NG, Heuts DP, Fraaije MW, van Berkel WJ (2006) Occurrence and biocatalytic potential of carbohydrate oxidases. Adv Appl Microbiol 60:17-54 van Hellemond EW, Vermote L, Koolen W, Sonke T, Zandvoort E, Heuts DPHM, Janssen DB, Fraaije MW (2009) Exploring the biocatalytic scope of alditol oxidase from Streptomyces coelicolor. Adv Synth Catal 351:1523-1530

Vihinen M (1987) Relationship of protein flexibility to thermostability. Protein Eng 1:477-480

Watanabe K, Masuda T, Ohashi H, Mihara H, Suzuki Y (1994) Multiple proline substitutions cumulatively thermostabilize Bacillus cereus ATCC7064 oligo-1,6-glucosidase-irrefragable proof supporting the proline rule. Eur J Biochem 226:277-283

Welch M, Govindarajan S, Ness JE, Villalobos A, Gurney A, Minshull J, Gustafsson C (2009) Design parameters to control synthetic gene expression in Escherichia coli. PLoS One 4:e7002

Westerbeek A, Szymański W, Wijma HJ, Marrink SJ, Feringa BL, Janssen DB (2011) Kinetic resolution of $\alpha$-bromoamides: experimental and theoretical investigation of highly enantioselective reactions catalyzed by haloalkane dehalogenases. Adv Synt Catal 353:931-944

Wohlgemuth R (2009) The locks and keys to industrial biotechnology. New Biotechnology 25:204-213

Wong OA, Shi Y (2008) Organocatalytic oxidation. Asymmetric epoxidation of olefins catalyzed by chiral ketones and iminium salts. Chem Rev 108:3958-3987

Yamashita M, Omura H, Okamoto E, Furuya Y, Yabuuchi M, Fukahi K, Murooka Y (2000) Isolation, characterization, and molecular cloning of a thermostable xylitol oxidase from Streptomyces $\mathrm{sp}$ IKD472. J Biosci Bioeng 89:350-360 